\title{
WORKFORCE AND EMPLOYMENT ESTIMATES: NEW ZEALAND 1921-1939
}

\author{
Keith Rankin \\ University Of Auckland
}

\begin{abstract}
New Zealand does not have a consistent set of employment and unemployment data for the interwar years. The best source is the Population Census which was held three times, but not during the Great Depression. There is also a consistent set of official factory statistics which commences in 1921, and can be separated into males and females, adults and minors. This paper uses an estimate for the 1933 workforce that is equivalent to the census data points of 1921,1926 and 1936. It also uses officially sourced employment estimates for 1939. From these data points, from the factory data, and from Post Office Savings Bank balances, a set of equations are constructed from which annual employment data are drawn. Workforce estimates for periods of high unemployment are interpolated in accordance with the subsequent recoveries. The 1920s was a period of insecurity and low female participation. The 1930s saw a transformation from mass unemployment to full employment in just six years, despite a rise in labour force participation.
\end{abstract}

The interwar years were a tumultuous period of New Zealand's labour history; years in which the general experiences were overwhelmed by those of the Great Depression of the early 1930 s. The interwar years were not years of prolonged slump; they were years in which technological change transformed the New Zealand way of life (Watson 1984) and years in which growth (especially in manufacturing and services) predominated despite the setbacks (Rankin 1992). The 1920 s were years of 'insecurity and instability' (Hawke 1985, p.102). The contented colony of the early 1900 s was facing up to the new realities of the second industrial revolution. There were always going to be some stresses and strains in the interwar labour market. How did it respond?

While widespread recollection of interwar hardship and insecurity came to pervade New Zealand's collective consciousness to an unusual extent, most of the scant quantitative literature suggests that unemployment in New Zealand was not as great as in other comparable countries (Olssen 1990, Hawke 1985 p.124, Macrae and Sinclair 1975). I have questioned this view (Rankin 1990,1995 ) by exploring the similarities and differences between the New Zealand and Australian experiences of the Depression, concluding that the two countries' experiences were comparable. Nevertheless, even allowing for the Hawke/ Olssen view, the contrast between the Depression and the years that followed was very great. The achievement of security - full employment, an insulated tradeables sector, and a universal welfare safety net - came to be embodied in the legendary portrait of Michael Joseph Savage, Prime Minister and father figure of the nation from 1936 to 1940.

\section{Concepts}

The concept of 'workforce' that I am using is somewhat different from the 'labour force' concept that is embodied in the modern Household Labour Force Survey. It is based on the premise that the workforce is a comparatively stable segment of the working age population. Indeed, the workforce is the remainder of the working-age population, once people who can be identified with other activity categories (eg student, homemaker, retired) have been deducted. Discouraged workers who are unable or unwilling to seek work via formal methods are therefore seen as being in the workforce. They are as much a part of any 'unemployment problem' as are the unambiguously unemployed.

As a result of my approach, I am most comfortable with the terms 'core employment' and 'residual workforce' as the key sub-divisions of the workforce. Core employment consists of those identified in the census tables as 'employers', 'working on own account', 'wage or salary earner' or 'apprentice'. The residual workforce is the remainder of the working-age population, once the non-workforce and the core employed have been accounted for.

Part-time employment was established as a new employment category in the 1933 and 1936 censuses. In the New Zealand census, the label was 'part-time unemployed'. The category 'relative assisting without pay' tended to rise with unemployment, while those who did not specify a workforce status had incomes commensurate with the unemployed. These three categories have been classified 
with the unemployed in the residual workforce.

The residual workforce included many females - single and married - who were classified in the census as being 'dependent'. The reclassifications ensured that female unemployment rates were never lower than male rates, and also reflected increased numbers of women with incomes. Many of those in the residual workforce were employed intermittently during the Depression; they had an income, albeit very low. Indeed, if a modem labour force survey had been taken in 1933 or 1936, the numbers of females classed as jobless or employed part-time would have been very high. In all probability, a clear majority of women in households adversely affected by the Depression would have been either seeking employment or available for work. Many, of course, were working on their own account; making and selling products such as handicrafts, home-baked food, fresh vegetables, eggs, as well as performing a variety of services for cash. Much of this also applies to teenage males. It is interesting to note, however, that during the Depression there was a tendency for jobless sons to stay on at school, whereas daughters were increasingly withheld from school (Rankin 1990, ch.3).

It is important to note that the following estimates apply only to the non-Maori population. Almost certainly, Maori unemployment rates were higher (Macrae and Sinclair 1975). The non-Maori population database has been easier to use when age disaggregation is required. Another problem relates to the marginalisation of Maori, away from the industrialised economy in which there was a clear distinction between being 'at work' and 'at home'. This problem should not be overstated, however, because Pakeha economic activity in the Depression years also became less formally structured.

\section{Estimating the Employment Series}

The starting point for any analysis of the New Zealand labour market in the inter-war period (1919-1939) is the Population Census. Three were conducted: 1921, 1926 and 1936. To estimate employment and workforce participation for the depth of the Great Depression, I have used the Australian census of 1933 as if it were a New Zealand census (Rankin 1990, Rankin 1995). The technique has been to adjust the Australian data, disaggregated by sex and age, to a New Zealand population base. To allow for the census understatement of female unemployment and casual employment, adjustments were made to the 1926, 1933 and 1936 female workforce (Rankin 1995). No adjustments were required for 1921 .

The census employment and benchmark workforce data are presented in table 1 . I have added employment benchmarks for 1939 derived from data taken from the Reports of the National Service Department (AJHR H-11A, 1945, 1230). 1945 census data are presented also so that a comparison can be made between the immediate pre-World War 2 period with the immediate post-war period, making it possible to separate changes in participation rates that took place in the 1930 s from others that occurred in the 1940s.

The 1939 benchmark has problems in that it can only be separated into adults and minors on the basis of educated guesswork. There is also concern that the 1939 female employment statistic may be inflated. Certainly the National Service Department estimates for females for 1945 were well above the census totals. The main problem appears to have been that many women who moved into factories and offices during the war were transferring from domestic service, but had been counted as additions to the workforce. The published 1939 data are based on Septem.

Table 1: Core employment and workforce benchmarks, New Zealand 1921-45

\begin{tabular}{|c|c|c|c|c|}
\hline & \multicolumn{2}{|c|}{ MALES } & \multicolumn{2}{|c|}{ FEMALES } \\
\hline & EMA & EMY & EFA & EFY \\
\hline \multicolumn{5}{|c|}{ Employment } \\
\hline 1921 & 307,088 & 42,344 & 67,700 & 32,400 \\
\hline 1926 & 367,960 & 58,306 & 74,892 & 35,030 \\
\hline 1933 & 307,088 & 42,344 & 76,000 & 30,600 \\
\hline 1936 & 380,063 & 59,637 & 93,237 & 40,357 \\
\hline 1939 & 445,000 & 75,000 & 132,000 & 43,000 \\
\hline 1945 & 408,200 & 54,300 & 111,600 & 48,600 \\
\hline \multicolumn{5}{|c|}{ Workforce } \\
\hline 1921 & 337,900 & 59,600 & 75,700 & 36,000 \\
\hline 1926 & 373,115 & 65,185 & 81,488 & 37,500 \\
\hline 1933 & 418,487 & 64,225 & 149,343 & 48,000 \\
\hline 1936 & 435,046 & 69,587 & 152,340 & 47,700 \\
\hline
\end{tabular}

Source: see text and appendix 1 
Table 2. Employment in New Zealand

factories, 1921-39.

\begin{tabular}{lllll}
\hline & \multicolumn{2}{c}{ MALES } & \multicolumn{2}{l}{ FEMALES } \\
& adult & youth & adult & youth \\
& FMA & FMY & FFA & FFY \\
\hline 1921 & 39,500 & 8,907 & 11,194 & 5,587 \\
1922 & 38,237 & 8,643 & 10,841 & 5,411 \\
1923 & 40,684 & 9,849 & 12,130 & 5,858 \\
1924 & 41,782 & 10,256 & 11,820 & 5,817 \\
1925 & 43,672 & 10,468 & 12,048 & 6,053 \\
1926 & 43,531 & 10,369 & 12,287 & 6,155 \\
1927 & 42,519 & 10,893 & 12,807 & 6,597 \\
1928 & 43,035 & 11,060 & 13,224 & 6,801 \\
1929 & 43,138 & 11,513 & 13,696 & 7,257 \\
1930 & 45,443 & 11,874 & 14,823 & 7,376 \\
1931 & 37,601 & 10,815 & 12,776 & 6,278 \\
1932 & 31,269 & 11,022 & 13,143 & 6,274 \\
1933 & 31,727 & 11,894 & 13,659 & 6,004 \\
1934 & 33,506 & 12,799 & 15,184 & 6,165 \\
1935 & 38,108 & 13,696 & 17,204 & 6,559 \\
1936 & 43,445 & 14,192 & 19,070 & 7,200 \\
1937 & 50,384 & 14,499 & 22,452 & 9,976 \\
1938 & 52,508 & 14,575 & 22,059 & 10,843 \\
1939 & 53,474 & 15,394 & 22,640 & 11,288
\end{tabular}

Source:NZ Census and Statistics Office (refer appendix 1) Note: Youths are workers aged 14-20 inclusive.

ber of that year. As 1939 was a year of quite high economic growth, I deducted 5,000 females to form the March employment benchmark, of 175,000 . Because of offsetting seasonal factors, I left the male employment benchmark at 520,000 .

To interpolate the benchmark employment data, I have used a multiple regression technique, with the key regressor being the factory workforce. Factory employment statistics were made available on a consistent basis from 1921 to 1939. Furthermore, they are broken down each year on the basis of wage rates. For each sex, the wages show a bi-modal distribution. I have concluded that the lower peak represents minors while the higher peak represents adult workers. By separating minors from adults, it has been possible to extract four regressor series from the factory data. They are presented in table 2.

The other main regressor used was Post Office Savings Bank balances ('POSB'). These are sensitive to the employment circumstances of ordinary families, whereas trading bank balances are biased in favour of the wealthier minority, and firms rather than households. My initial line estimations ('simple regressions' in table 4) have used just four years as data points (ie excluding the less reliable 1939 benchmark). From these regressions, I estimated the most probable breakdown between adults and minors for 1939.

There was a fall in Post Office funds after 1938 which cannot be explained by reduced economic activity. Therefore Ihave included a dummy variable regressor('PDUM') to account for the year 1939. For my final line estimations, I have made use of two other regressors: GNP per capita ('GNPC'), and the general price level ('PRICE'). The supplementary regressor series are presented in table 3.

Table 4 presents the line estimation equations that I have used for inter-benchmark interpolation. (The 'PRICE' regressor gave a better fit than 'PDUM' for adults, whereas 'PDUM' was preferred for minors.) The resulting employment estimates are tabulated in appendix 2 . The time series are shown below in figure 1 .

The employment estimates need to be interpreted with some care. In particular, the extent of the fluctuations in teenage employment in the late 1920 s should be treated with a degree of scepticism. Nevertheless, there are grounds for accepting that these estimates are valid. 1927 did represent a very sharp downturn in the provincial

Table 3. Series of regressors used to generate the employment functions

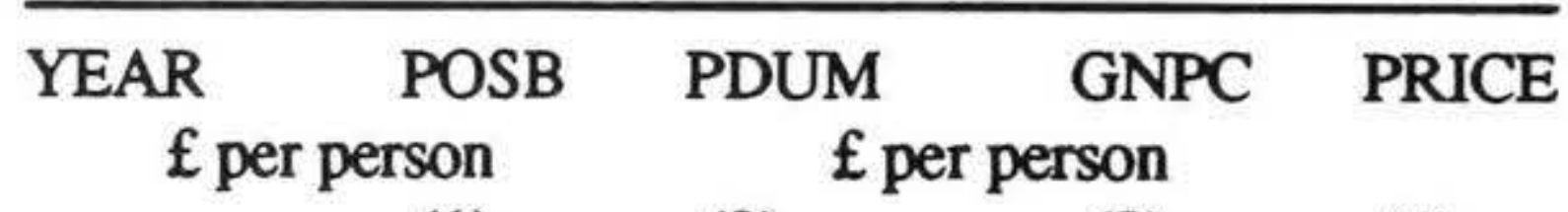

(2)

(3)

(4)

\begin{tabular}{lllll}
\hline 1921 & 34.20 & 0 & 75.0 & 1906 \\
1922 & 33.69 & 0 & 70.8 & 1613 \\
1923 & 33.47 & 0 & 75.2 & 1618 \\
1924 & 34.20 & 0 & 75.1 & 1674 \\
1925 & 34.03 & 0 & 77.5 & 1688 \\
1926 & 33.98 & 0 & 71.9 & 1619 \\
1927 & 34.06 & 0 & 68.7 & 1564 \\
1928 & 32.85 & 0 & 75.5 & 1586 \\
1929 & 33.07 & 0 & 77.3 & 1585 \\
1930 & 33.20 & 0 & 73.0 & 1523 \\
1931 & 31.53 & 0 & 65.9 & 1344 \\
1932 & 28.35 & 0 & 63.7 & 1263 \\
1933 & 27.33 & 0 & 67.5 & 1249 \\
1934 & 28.95 & 0 & 70.4 & 1284 \\
1935 & 31.66 & 0 & 73.3 & 1383 \\
1936 & 33.62 & 0 & 86.4 & 1419 \\
1937 & 36.58 & 0 & 90.4 & 1522 \\
1938 & 39.36 & 0 & 95.8 & 1555 \\
1939 & 37.37 & 1 & 95.9 & 1657
\end{tabular}

Notes

(1)Post Office Savings Bank balances (nominal) per capita (incl. Maoris), in NZf.

(2)Dummy variable to exclude the 1939 data, which does not originate from any population census.

(3)Real Gross National Product per capita, in

NZf1910/11.

(4)Wholesale Price Index, excl. imports $(1000=1910 /$ 11).

Source:Bloomfield, pp.391-392 Rankin 1992, Tables 3 \& 4 
Figure 1. Inter-war employment estimates

a. Males (over 21)

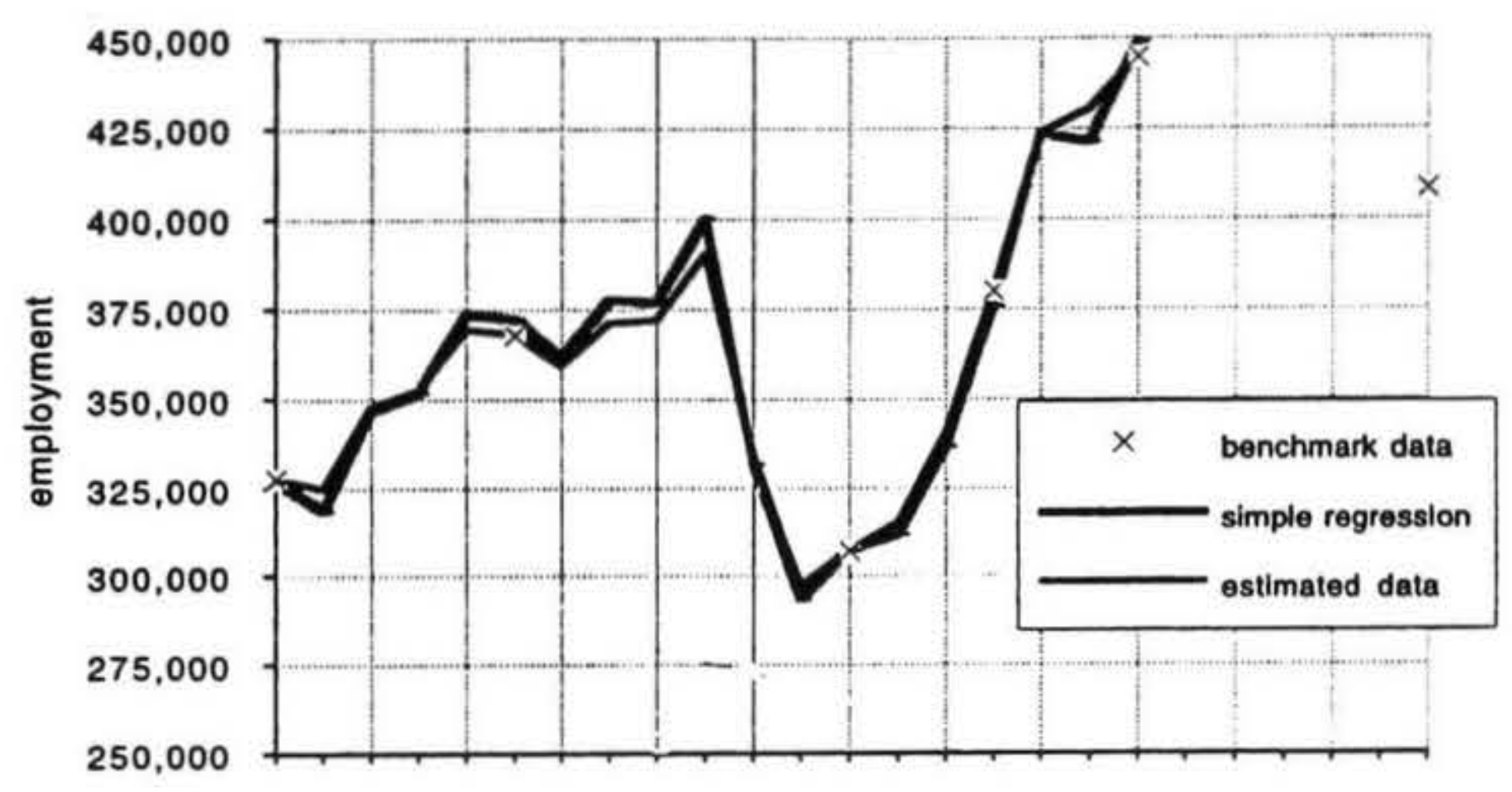

b. Males under 21

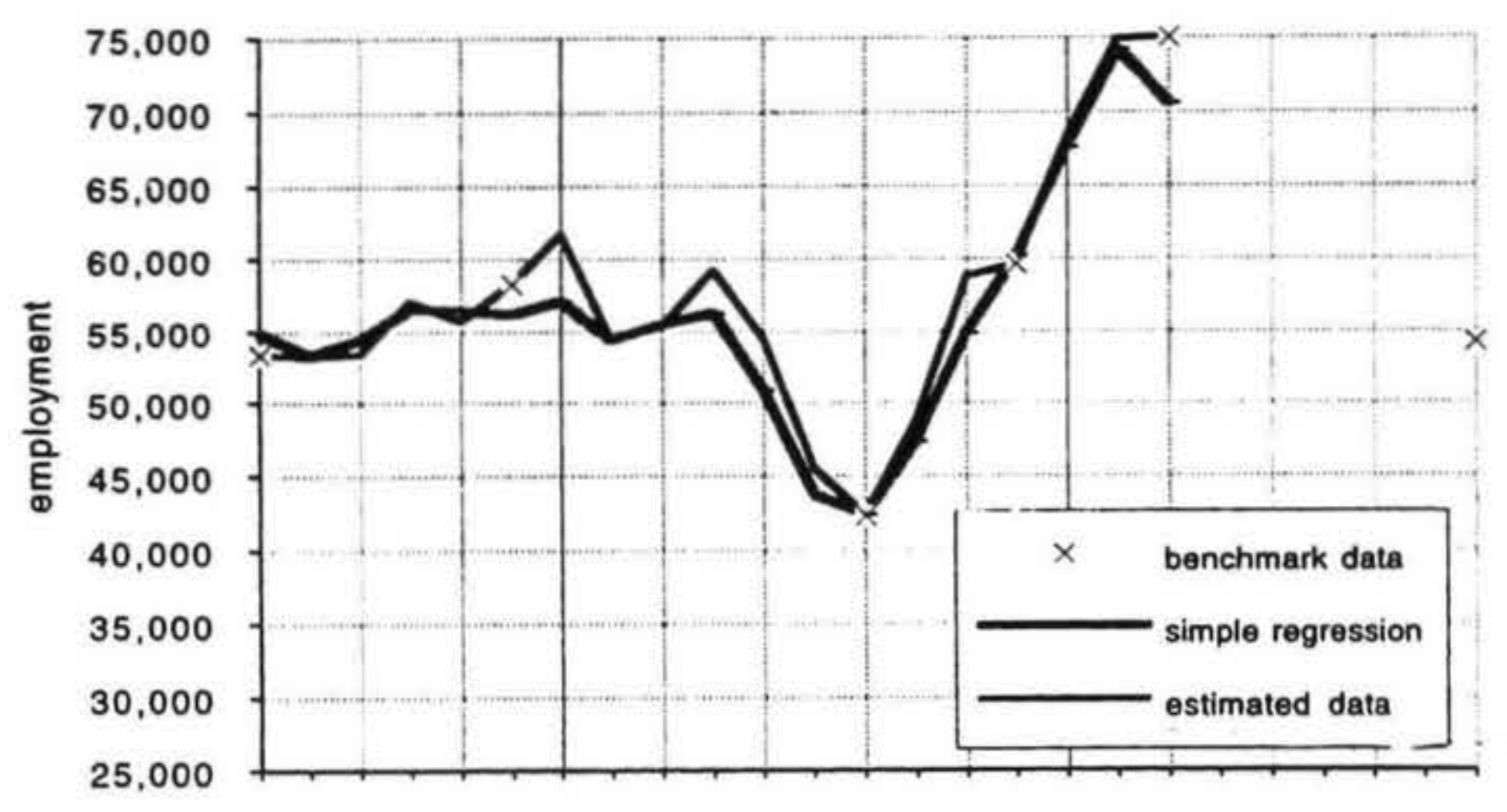

c. Females over 21

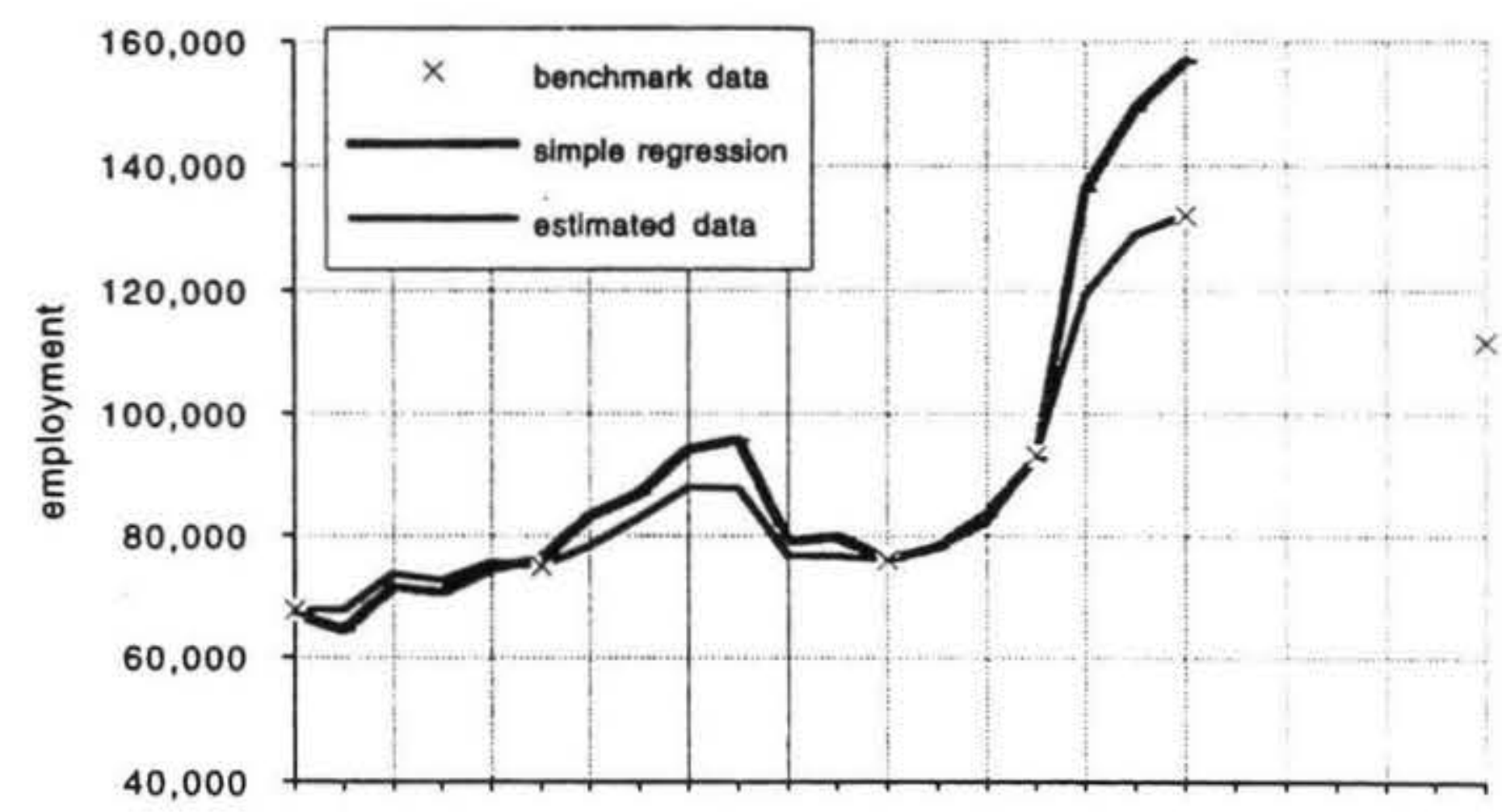

d. Females under 21

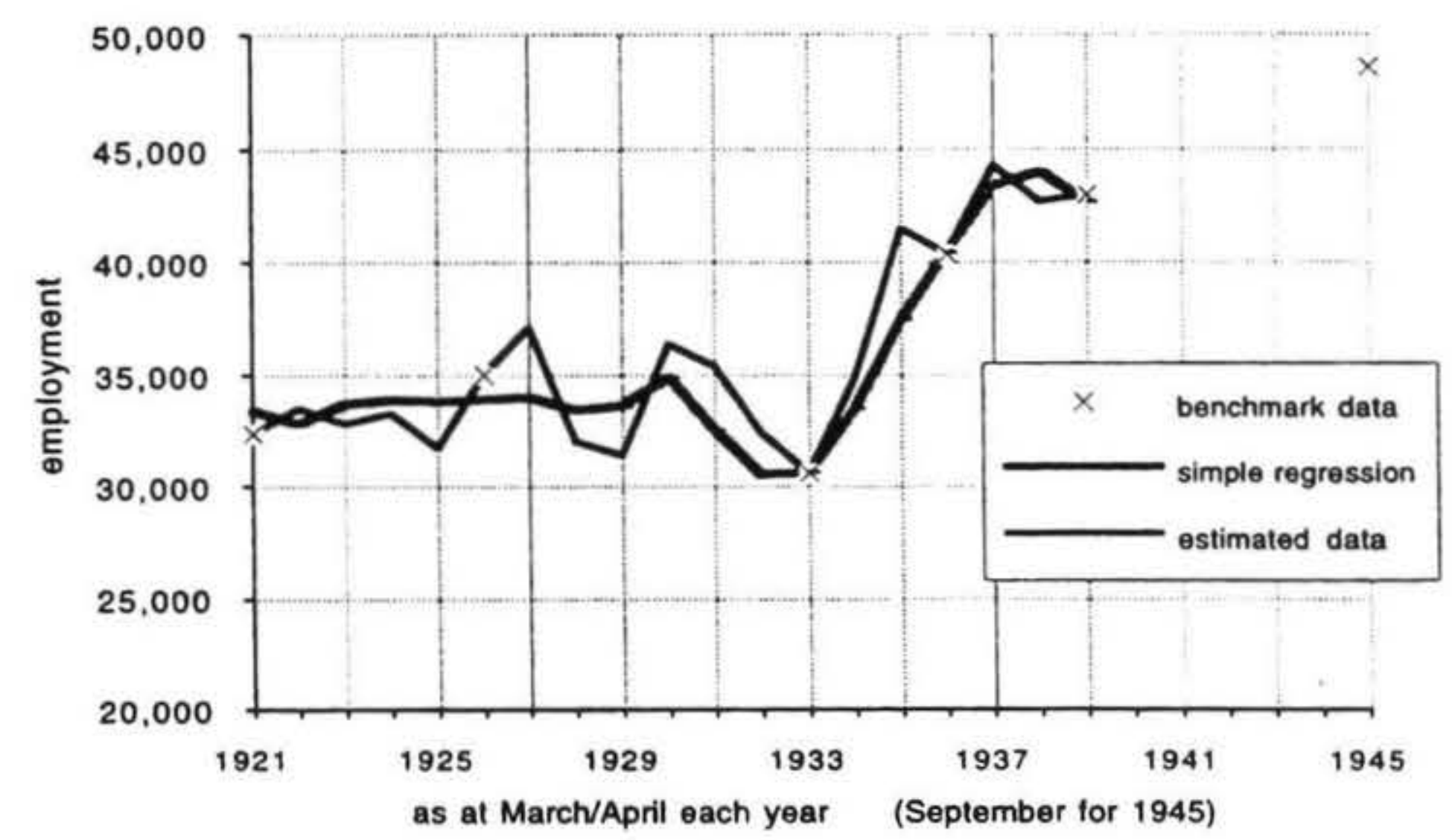


hinterlands; many teenagers who left school to support their families must have found work at the expense of their elders who were highly paid (Rankin 1990:155-56). Many of those extra teenage workers will have retained their jobs as they became adults. However, there was not enough job growth to satisfy new workforce entrants in the summers of $1927 / 28$ and $1928 / 29$ (Neale 1929 p.81). A similar situation occurred in 1935/36, after teenage employment growth led the post-Depression recovery. In the late 1920 s, there was a drift of young people to the towns (Fisher 1929).

The comparisons between 1939 and 1945 are interesting, in that they show that it was the Depression rather than the War which acted to bring women into the workforce. Certainly the employment rate of single women picked up during the World War 2, but that was offset by more women getting married and starting families. Surprisingly, male employment rates fell during the war years. As Ruth (1950) pointed out, it was the greater access to alternatives to employment - especially retirement and education - that underpinned the falling male unemployment rates during the $1940 \mathrm{~s}$.

\section{Workforce Estimates}

Annual workforce estimates were derived by joining the benchmark workforce participation rates in accordance with three basic rules. In years of declining employment, participation rates for teenagers and females were raised because of the added-worker effect. That is, periods of negative growth are linked to an influx of non-traditional workers seeking to supplement household incomes in the face of redundancy, short-time or wage cuts to primary breadwinners (adult males, by social convention). Recovery phases see a constant participation rate as the workforce becomes less unemployed. Once post-recovery expansion takes hold, non-traditional workers tend to leave the workforce, for example to start families.

A ratchet effect clearly took place, however, from the late 1920 s, leaving women with permanently higher participation rates. The periods of falling participation rates were not long enough to offset the rapid influx of job seekers during the downturns. This trend of rising female participation was accentuated by structural change favouring the growth of new occupations around which male cultures had not developed.

Estimated workforce participation and employment rates are presented in figure 2.

Male minors show a big decline in participation in the Depression if the census benchmarks are used. However, it is clear that male teenagers' patterns of workforce activity were strongly correlated with those of female minors. I did not adjust the census benchmarks for teenage males, as I did for females (in Rankin 1995). Instead, as is shown in figure $2 b$, I have overridden theircensus workforce participation rates. The recovery reveals a high rate of male teenagers wanting work during the Depression. It is not plausible that fewer teenagers wanted to work in 1933 than in 1938.

The estimates of the entire workforce are tabulated in appendix 2, along with the core employment data. The workforce includes a few people aged less than 14 , plus many aged over 65 . All of those in the workforce not classed as being in core employment come into the residual workforce category, a broad measure of unemployment.

Table 4. Estimated Employment Functions for New Zealand, 1921-1939.

Male Adults

a) $\quad \mathrm{EMA}=110.8 * \mathrm{YEAR}+10.6 * \mathrm{FMA}-8873 * \mathrm{POSB} \quad$ simple regression $\quad\left[\mathrm{t}=5.7,6.6,3.3 ; \mathrm{R}^{2}=0.989\right]$

$\mathrm{EMA}=99.6 * \mathrm{YEAR}+9.27 * \mathrm{FMA}-7842 * \mathrm{POSB}+528 * \mathrm{GNPC} \quad\left[\mathrm{t}=7.9,11.5,6.2,1.6 ; \mathrm{R}^{2}=0.999\right]$

$\mathrm{EMA}=86.5 * \mathrm{YEAR}+8.27 * \mathrm{FMA}-4418 * \mathrm{POSB}+397 * \mathrm{GNPC}-22.9 * \mathrm{PRICE}$

Male Youths

b) $\quad \mathrm{EMY}=-19.6 * \mathrm{YEAR}+1.32 * \mathrm{FMY}+2361 * \mathrm{POSB} \quad$ simple regression $\quad\left[\mathrm{t}=2.0,1.86,5.0 ; \mathrm{R}^{2}=0.962\right]$

$\mathrm{EMY}=-30.6 * \mathrm{YEAR}+3.20 * \mathrm{FMY}+3605 * \mathrm{POSB}-531 * \mathrm{GNPC} \quad\left[\mathrm{t}=4.3,2.2,3.7,1.08 ; \mathrm{R}^{2}=0.989\right]$

$\mathrm{EMY}=-24.0 * \mathrm{YEAR}+2.80 * \mathrm{FMY}+3374 * \mathrm{POSB}-544 * \mathrm{GNPC}+4556 * \mathrm{PDUM}$

Female Adults

c) $\mathrm{EFA}=-5.21 * \mathrm{YEAR}+16.0 * \mathrm{FFA}-358 * \mathrm{POSB}$ simple regression $\left[\mathrm{t}=.96,12.6,1.4 ; \mathrm{R}^{2}=0.994\right]$

$\mathrm{EFA}=4.41^{*} \mathrm{YEAR}+9.41 * \mathrm{FFA}-1066 * \mathrm{POSB}+599^{*} \mathrm{GNPC} \quad\left[\mathrm{t}=.60,7.4,1.8,1.8 ; \mathrm{R}^{2}=0.997\right]$

$\mathrm{EFA}=3.22 * \mathrm{YEAR}+9.15 * \mathrm{FFA}-17.3 * \mathrm{POSB}+442 * \mathrm{GNPC}-11.6 * \mathrm{PRICE}$

Female Youths

d) $\quad \mathrm{EFY}=0.398^{*} \mathrm{YEAR}+1.19 * \mathrm{FFY}+759 * \mathrm{POSB} \quad$ simple regression $\quad\left[\mathrm{t}=2.0,1.86,5.0 ; \mathrm{R}^{2}=0.956\right]$

$\mathrm{EFY}=-0.255^{*} \mathrm{YEAR}+1.73 * \mathrm{FFY}+1146 * \mathrm{POSB}-203^{*} \mathrm{GNPC} \quad\left[\mathrm{t}=0.08,2.13,1.97,0.67 ; \mathrm{R}^{2}=0.985\right]$

$\mathrm{EFY}=3.05 * \mathrm{YEAR}+2.41 * \mathrm{FFY}+1586 * \mathrm{POSB}-550 * \mathrm{GNPC}+3125 * \mathrm{PDUM}$ 
Figure 2. Inter-war workforce participation rates, New Zealand

Males aged 21-64

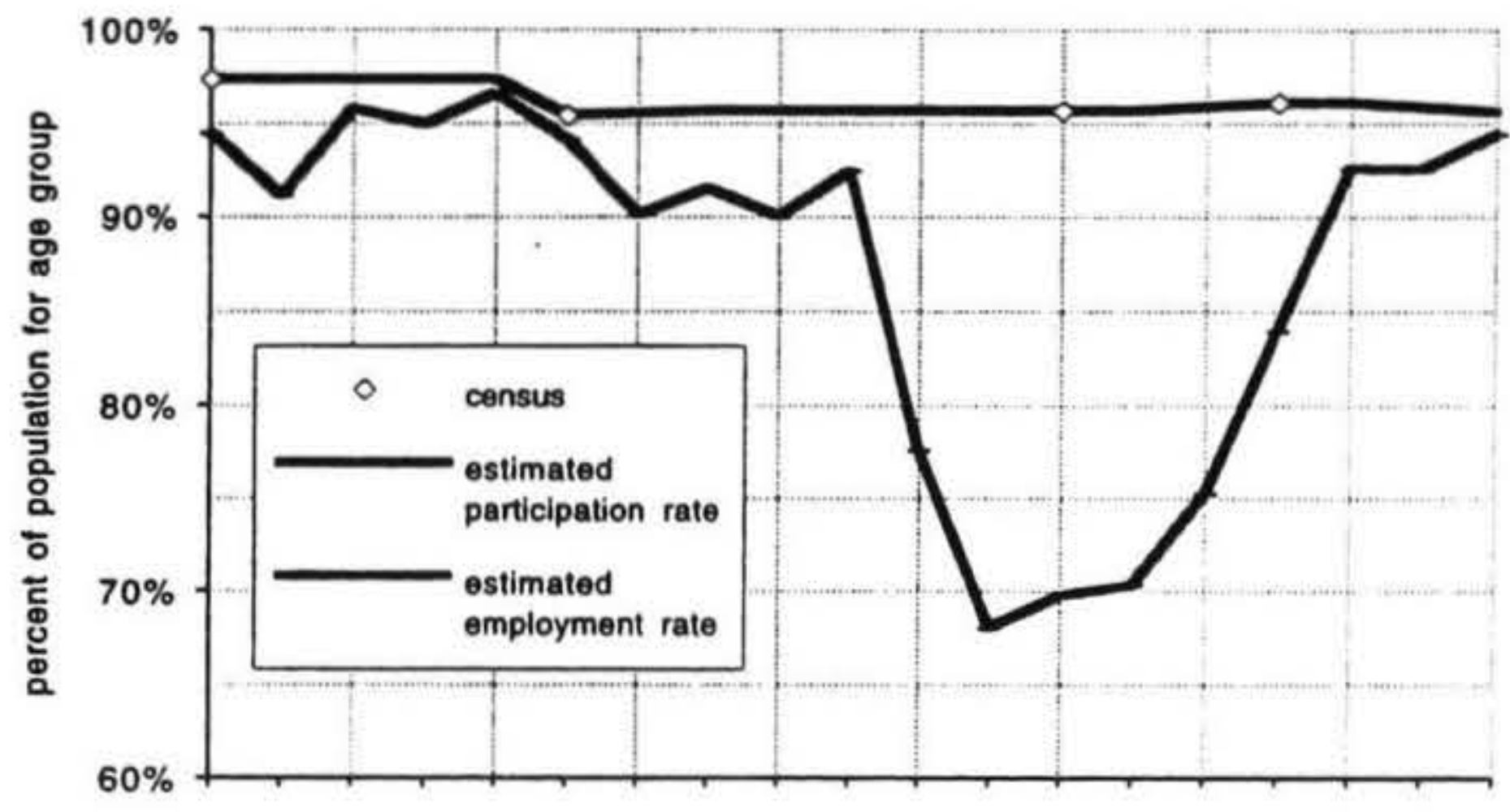

Males aged 14-20

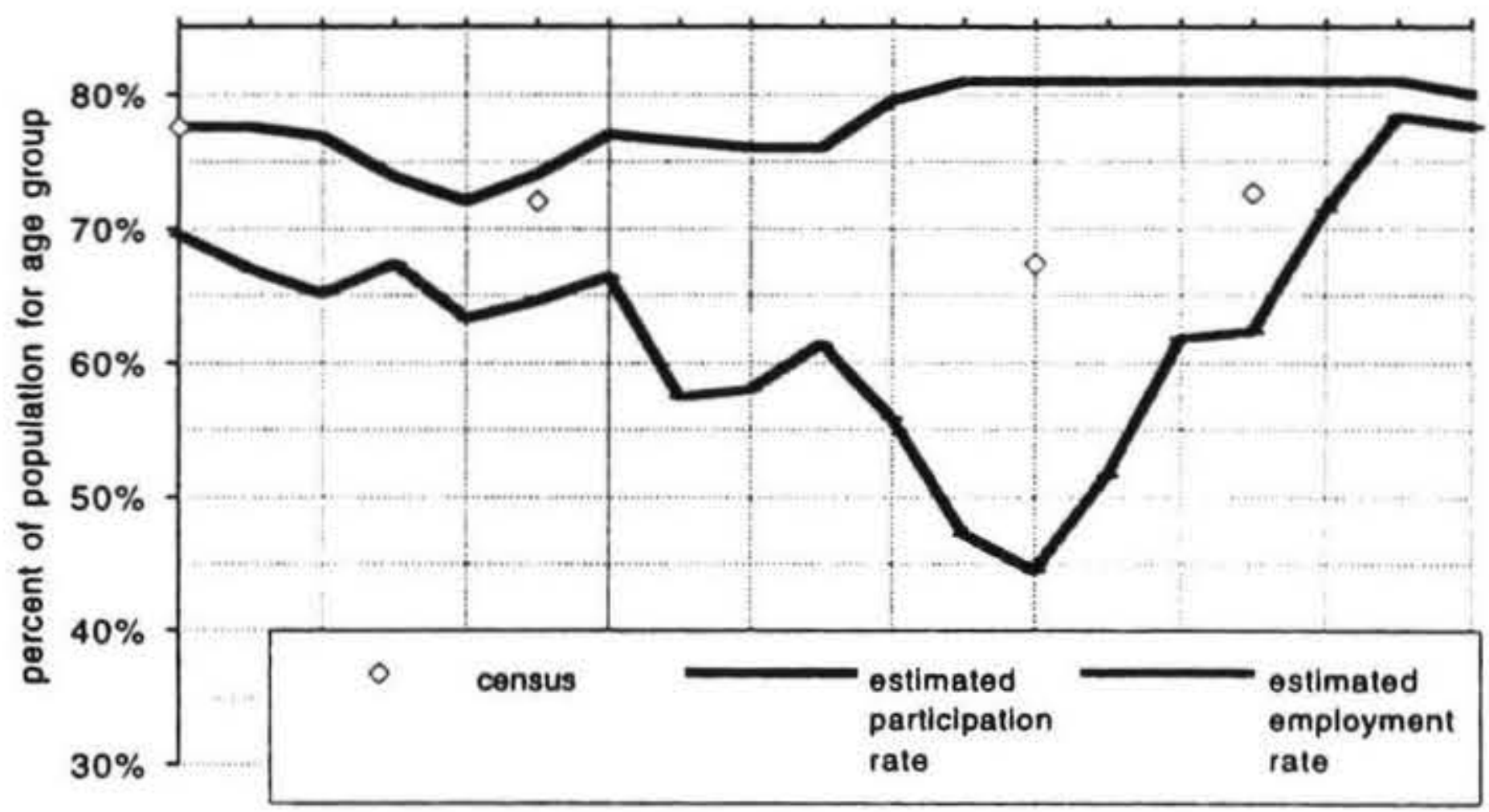

Females aged 21-64

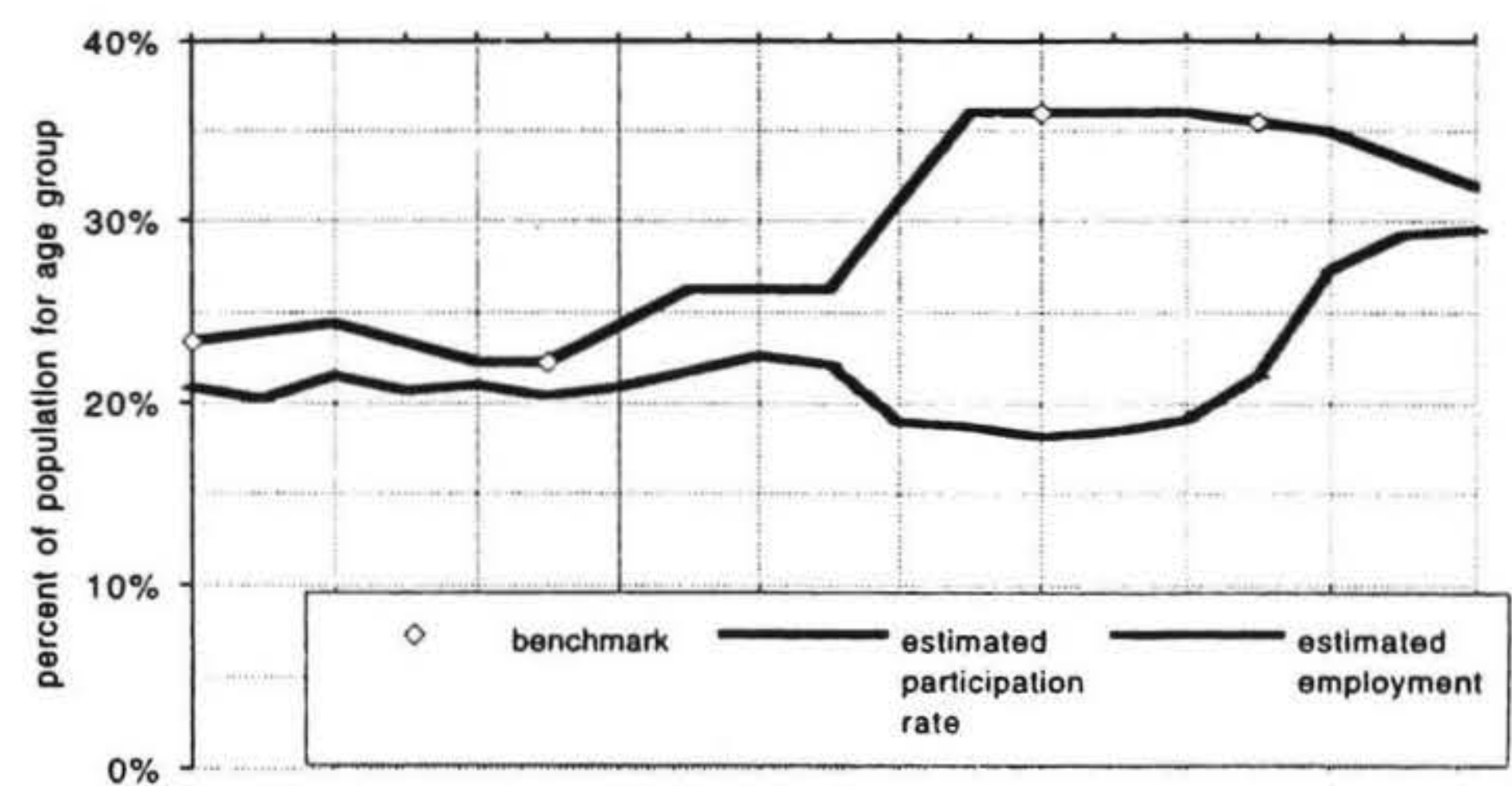

Females aged 14-20

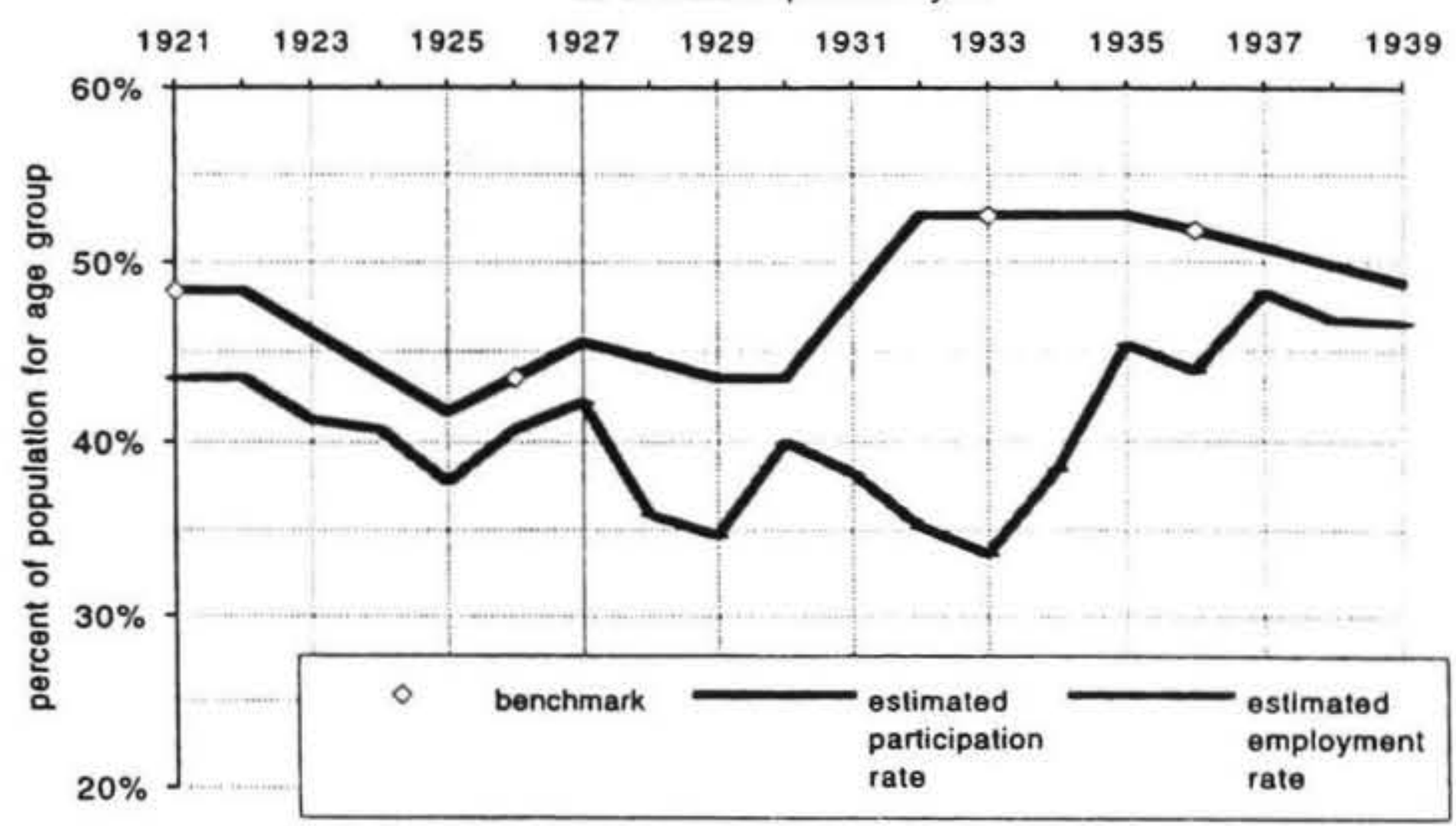




\section{Unemployment Estimates}

Appendix 2 divides the workforce into its two constituent parts. The resulting unemployment rates reflect the same kind of pattern that was present in Australia, the United States and Canada. Joblessness peaked during the winter of 1932 , exceeding $35 \%$ of the workforce: 240,000 men, women and teenagers. This is remarkably similar to the 'ballpark' estimate used by Elizabeth McCombs in Parliament (NZPD, 28 September 1933) based on a similar definition of unemployment.

Appendix 3 sub-divides the working-age population. Of major significance is the non-participation rate. For teenagers, the full-employment year of 1925 clearly coincides with the highest non-participation rates. The table suggests that $9 \%$ of males aged $14-20$ were obliged to enter the workforce as a result of deteriorating economic conditions from the late 1920s. For young females, the equivalent figure is $11 \%$. For adult females, with the highest non-participation rates, an estimated $14 \%$ wanted to work who would not have so wished in 1925 . This is confirmed by the much lower fertility rates and marriage rates between 1926 and 1936 (Rankin 1990, ch.2). Because adult male participation rates were much higher in the inter-war years than they are now, by any measure of participation, unemployment rates tended to be higher than they have been in recent years, for similar levels of employment.

I have suggested elsewhere (Rankin 1994) that the drop in median per capita real incomes may have been as great as $50 \%$ from 1930 to 1933 . This relationship is inferred from a comparison between census median incomes and time series of GNP per capita. This certainly underpins the big drop in employment, and suggests that the $26 \%$ fall in male adult core employment rates (from $86.5 \%$ to $64.1 \%$ ) may have only been part of the story. In Broomhill's account of South Australian conditions in 1931-32 (Broomhill 1974), only one-third of the male workforce was fully employed; ie neither unemployed nor underemployed. Australia's recovery was well under way at the time its census was taken, whereas New Zealand's registered unemployment was at its peak. There is no hard evidence that New Zealand's experience of underemployment was less marked than Australia's. Hours worked by male wage earners almost certainly fell by much more than $26 \%$.

\section{Conclusion}

How would this paper's estimates compare with estimates consistent with modern labour force surveys? My view is that male labour force participation rates would have been, at least for the Depression years, somewhat lower under HLFS criteria, while employment rates would have been higher, with many more men - for example those on relief work - being classed as employed. On the other hand, it is likely that a modern survey would have counted many more women as unemployed - or at least jobless, given the lack of channels through which women could 'actively seek' employment - than I have estimated here.

Women were seen as taking men's jobs, and were even more ardently discriminated against in the mid-1930s than in the 1920s. Nevertheless, the structural changes in the wider economy reinforced the market and political responses to the Depression, creating new employment opportunities in the late 1930s for female job-seekers and, in the 1940s, more leisure opportunities for men.

My estimates for peak inter-war unemployment involve a relatively liberal interpretation of the term 'unemployment'. However, within that interpretation, these unemployment estimates may be conservative. Income data suggest a huge fall in wages paid. Female employment rates were low by today's standards, in the 1920 s as well as during the Depression. That means that there was much more scope for people to enter the workforce (or remain in the workforce) in response to a household budgeting crisis than there is in the $1990 \mathrm{~s}$. Thus, very high rates of female unemployment were plausible in the inter-war context, given the potentially high transfer rates of females from non-participation to unemployment.

Unemployment during the interwar years was significantly higher than official estimates used at the time and, later, by social and economic historians. New Zealand's unemployment levels were not different from those of comparable English speaking countries. New Zealand was however unique in the extent and speed of its recovery. A different perception of normalcy made the Depression seem particularly great.

\section{Future Research}

This paper gives a sketch of aggregate labour market activity during the Great Depression in relation to the rest of the interwar period, in the form of time series that can be used in econometric studies.

As well as facilitating such quantitative research, the data presented here can be used to further understand presentday labour markets. Historical context is important in the understanding of labour supply and labour demand. Are the trade-offs being made by families and individuals between paid work, unpaid work and leisure - different today because our history has changed our values and our range of choices? Or can we predict future developments in labour supply from the kinds of responses that people made during the stressful interwar years? How does technological change affect the demand for labour? The interwar years give an insight to the workings of job creation under conditions of instability, disequilibrium and changing production functions.

My present work can be extended in three different directions. First, comparable Maori workforce estimates should be synthesised. Second, we need annual employment data disaggregated by sector. These data will necessarily include Maori, because private sources such as archived business records will not have discriminated between Maori and non-Maori. Third, we need employment and workforce estimates that extend back well into the nineteenth century. 
There is also a need to understand the labour market by examining (from literary and oral history as well as quantitative sources) changes in the activity preferences of all segments of the population; to learn about the way household decisions which affect the extent of individuals' attachment to the labour force have been made. Employment is a means to other ends - essentially disposable income but also social belonging, indeed social status. Employment is a cost rather than a benefit that involves leasing our time to someone else in order to achieve these ends. Work, on the other hand, can have other rewards; eg the satisfaction of producing something, or of raising a family.

Labour market research needs to focus more on the distinction between means and ends, and the distinction between employment and work. Otherwise we tend to assume that employment is an end in itself; a good that successful labour markets produce in high quantities. My study of the interwar period suggests that rising female labour supply was a cost borne by families in distress; a cost which nevertheless satisfied a number of ends, ex post. It is now time to investigate ways in which the benefits high levels of employment have given us can be achieved by other means. We can learn from the way the 1920s' labour market was evolving before being hit by the Great Depression; from the fact that the majority of households had gained discretion over how family members spent their time. That period was characterised by low participation rates, rising leisure and socialisation through voluntary activities, and large scale transfer payments (albeit within households). The unnecessary gender bias and internalisation of transfer payments aside, the early 1920s may be able to teach us something about how labour markets can operate successfully without providing for mass employment. What are the opportunity costs of high participation rates? The interwar period can give us some clues.

\section{References}

Australia 1933. Census of the Commonwealth of Australia.

Bloomfield, G.T. 1984 A Handbook of New Zealand Statistics, Hall \& Co., Boston

Broomhill, R. 1974 Underemployment in Adelaide during the Depression, Labour History 27:31-40.

Hawke, G.R. 1985 The Making of New Zealand, Cambridge University Press, Cambridge.

Fisher, A.G.B. 1929 The drift to the towns, Economic Record, 5(2):234-252.

Macrae, J. and Sinclair, K. 1975 Unemployment in New Zealand during the Depression of the late 1920 s and early 1930s, Australian Economic History Review, 15(1): 35-45.

Neale, E.P. 1929 The post-war sex and age constitution of the New Zealand population, Economic Record 5(1):
75-82.

New Zealand. Appendices to the Journal of the House of Representatives (AJHR)

New Zealand. New Zealand Parliamentary Debates (NZPD)

New Zealand Census and Statistics Office, various years. Population Census (NZPC).

New Zealand Census and Statistics Office, annual. Official Yearbook (NZOYB)

New Zealand Census and Statistics Office, annual. Statistics of Population and Buildings

New Zealand Census and Statistics Office, annual. Statistical Reports on Factory and Building Production

New Zealand. Statistics New Zealand. Household Labour Force Survey (HLFS).

Olssen, E. 1990, History as morality, New Zealand Listener, 13 August, p.110

Rankin, K. 1990 Labour supply in New Zealand and Australia, 1919-1939. Unpublished thesis, Victoria University of Wellington.

Rankin, K. 1992 New Zealand's gross national product: 1859-1939', Review of Income \& Wealth 38(1):4969.

Rankin, K. 1994 'Comment: how great was the Depression in New Zealand?', New Zealand Economic Papers 28(2): 205-209.

Rankin, K. 1995 Unemployment in New Zealand at the peak of the Great Depression Working Paper No. 144, Economics Department, University of Auckland.

Ruth, N. 1950 Full Employment in New Zealand, Economic Record, 26(1):98-103.

Watson, J. 1984 Crisis and Change: economic crisis and technological change between the world wars, with special reference to Christchurch, 1926-36: $\mathrm{PhD}$ Thesis, University of Canterbury. New Zealand.

\section{Author}

Keith Rankin is an Assistant Lecturer in Economic History in the Economics Department of the University of Auckland, Private Bag 92019, Auckland.

\section{Appendix 1: Note on sources.}

All of the data presented in figures 1 and 2, and in the Appendix tables are my estimates of the size and composition of the New Zealand workforce from 1921 to 1939. 
The census employment benchmarks presented in table 1 come from the various population censuses cited (the volumes on Industries and Occupations). The key table is that of employment status (or grade) against sex and age cohort. In the Australian Census of 1933, the data is presented in tables 14 \& 15, of chapter XXIV (pp.275-276). Benchmark data for the male workforce were derived from the same census tables, as were the 1921 female workforce statistics. For the other female workforce benchmarks the census data were modified as per table 10 of Rankin (1995).

Population data disaggregated by age, are taken from the censuses, or from the official inter-censal estimates given in the Statistics of Population and Buildings. Where possible, mean calendar year data has been used. Otherwise, the data represents March or April of the year in question. The population data and the census data on employment status are exclusive of Maoris.

1939 employment data used in table 1 is taken from the National Service Department (AJHR, H-11A). During World War 2, the Labour Department was expanded, becoming the NSD. As there was a strategic need for more information about the labour force, so annual employment statistics commenced. The NSD data was the precursor of the half-yearly and quarterly employment surveys, conducted by the Department of Labour from 1946 until 1988.. The NSD mainly had information about the modern sectors, and therefore aggregate data cited from this source should be used with caution. Certainly, the NSD underestimated the attrition from domestic service.

The data presented in table 2 is derived from tables of factory employment disaggregated by wage rates, found in the New Zealand Yearbooks (NZOYB) and in the annual Statistics of Factory Production.

A useful source which summarises official historical data on all aspects of the New Zealand economy is Bloomfield (1984). I have not used Bloomfield as a major source because of my need for disaggregated annual data. However, I have used Bloomfield as a convenient source for financial data.

Appendix 2. New Zealand's Workforce, 1921-1939

\begin{tabular}{|c|c|c|c|c|c|}
\hline $\begin{array}{l}\text { March } \\
\text { est. }\end{array}$ & MALES & FEMALES & TOTAL & $\begin{array}{r}\text { MINORS } \\
\text { under } 21\end{array}$ & $\begin{array}{r}\text { ADULTS } \\
\text { over } 21\end{array}$ \\
\hline \multicolumn{6}{|c|}{ Workforce } \\
\hline 1921 & 397,500 & 111,700 & 509,200 & 95,600 & 413,600 \\
\hline 1922 & 408,600 & 117,100 & 525,700 & 98,800 & 426,900 \\
\hline 1923 & 416,700 & 120,100 & 536,800 & 99,800 & 437,000 \\
\hline 1924 & 423,900 & 117,400 & 541,300 & 98,500 & 442,800 \\
\hline 1925 & 435,700 & 114,900 & 550,600 & 98,500 & 452,100 \\
\hline 1926 & 440,100 & 119,000 & 559,100 & 104,400 & 454,700 \\
\hline 1927 & 452,700 & 130,700 & 583,400 & 111,500 & 471,900 \\
\hline 1928 & 460,500 & 139,700 & 600,200 & 112,200 & 488,000 \\
\hline 1929 & 468,300 & 141,300 & 609,600 & 112,200 & 497,400 \\
\hline 1930 & 477,300 & 143,500 & 620,800 & 113,000 & 507,800 \\
\hline 1931 & 488,100 & 169,800 & 657,900 & 122,000 & 535,900 \\
\hline 1932 & 492,700 & 195,600 & 688,300 & 126,800 & 561,500 \\
\hline 1933 & 495,600 & 197,300 & 692,900 & 125,100 & 567,800 \\
\hline 1934 & 502,500 & 199,300 & 701,800 & 124,500 & 577,300 \\
\hline 1935 & 509,100 & 201,200 & 710,300 & 125,300 & 585,000 \\
\hline 1936 & 512,600 & 200,000 & 712,600 & 125,200 & 587,400 \\
\hline 1937 & 518,400 & 198,600 & 717,000 & 124,300 & 592,700 \\
\hline 1938 & 523,200 & 192,900 & 716,100 & 123,000 & 593,100 \\
\hline 1939 & 528,500 & 187,900 & 716,400 & 122,500 & 593,900 \\
\hline
\end{tabular}

Core Employment

$\begin{array}{llllll}1921 & 381,300 & 100,100 & 481,400 & 85,800 & 395,600 \\ 1922 & 378,000 & 101,200 & 479,200 & 86,700 & 392,500 \\ 1923 & 401,200 & 106,400 & 507,600 & 86,200 & 421,400 \\ 1924 & 409,500 & 105,800 & 515,300 & 90,400 & 424,900 \\ 1925 & 425,100 & 107,300 & 532,400 & 87,400 & 445,000 \\ 1926 & 426,300 & 109,920 & 536,220 & 93,330 & 442,890 \\ 1927 & 421,000 & 115,300 & 536,300 & 98,800 & 437,500 \\ 1928 & 425,600 & 114,800 & 540,400 & 86,400 & 454,000\end{array}$




$\begin{array}{rrrrrr}1929 & 427,400 & 119,200 & 546,600 & 86,800 & 459,800 \\ 1930 & 449,400 & 124,100 & 573,500 & 95,600 & 477,900 \\ 1931 & 388,600 & 112,000 & 500,600 & 89,900 & 410,700 \\ 1932 & 342,300 & 109,000 & 451,300 & 77,900 & 373,400 \\ 1933 & 349,400 & 106,600 & 456,000 & 72,900 & 383,100 \\ 1934 & 363,800 & 113,200 & 477,000 & 83,600 & 393,400 \\ 1935 & 398,900 & 123,500 & 522,400 & 100,300 & 422,100 \\ 1936 & 439,700 & 133,600 & 573,300 & 99,960 & 473,340 \\ 1937 & 492,000 & 163,500 & 655,500 & 112,600 & 542,900 \\ 1938 & 505,300 & 171,700 & 677,000 & 117,600 & 559,400 \\ 1939 & 520,000 & 175,000 & 695,000 & 118,000 & 577,000\end{array}$

\section{Residual Workforce (“Unemployment”)}

$\begin{array}{rrrrrr}1921 & 16,200 & 11,600 & 27,800 & 9,800 & 18,000 \\ 1922 & 30,600 & 15,900 & 46,500 & 12,100 & 34,400 \\ 1923 & 15,500 & 13,700 & 29,200 & 13,600 & 15,600 \\ 1924 & 14,400 & 11,600 & 26,000 & 8,100 & 17,900 \\ 1925 & 10,600 & 7,600 & 18,200 & 11,100 & 7,100 \\ 1926 & 13,800 & 9,080 & 22,880 & 11,070 & 11,810 \\ 1927 & 31,700 & 15,400 & 47,100 & 12,700 & 34,400 \\ 1928 & 34,900 & 24,900 & 59,800 & 25,800 & 34,000 \\ 1929 & 40,900 & 22,100 & 63,000 & 25,400 & 37,600 \\ 1930 & 27,900 & 19,400 & 47,300 & 17,400 & 29,900 \\ 1931 & 99,500 & 57,800 & 157,300 & 32,100 & 125,200 \\ 1932 & 150,400 & 86,600 & 237,000 & 48,900 & 188,100 \\ 1933 & 146,200 & 90,700 & 236,900 & 52,200 & 184,700 \\ 1934 & 138,700 & 86,100 & 224,800 & 40,900 & 183,900 \\ 1935 & 110,200 & 77,700 & 187,900 & 25,000 & 162,900 \\ 1936 & 72,900 & 66,400 & 139,300 & 25,240 & 114,060 \\ 1937 & 26,400 & 35,100 & 61,500 & 11,700 & 49,800 \\ 1938 & 17,900 & 21,200 & 39,100 & 5,400 & 33,700 \\ 1939 & 8,500 & 12,900 & 21,400 & 4,500 & 16,900\end{array}$

\section{Unemployment Rate}

$\begin{array}{lrrrrr}1921 & 4.1 \% & 10.4 \% & 5.5 \% & 10.3 \% & 4.4 \% \\ 1922 & 7.5 \% & 13.6 \% & 8.8 \% & 12.2 \% & 8.1 \% \\ 1923 & 3.7 \% & 11.4 \% & 5.4 \% & 13.6 \% & 3.6 \% \\ 1924 & 3.4 \% & 9.9 \% & 4.8 \% & 8.2 \% & 4.0 \% \\ 1925 & 2.4 \% & 6.6 \% & 3.3 \% & 11.3 \% & 1.6 \% \\ 1926 & 3.1 \% & 7.6 \% & 4.1 \% & 10.6 \% & 2.6 \% \\ 1927 & 7.0 \% & 11.8 \% & 8.1 \% & 11.4 \% & 7.3 \% \\ 1928 & 7.6 \% & 17.8 \% & 10.0 \% & 23.0 \% & 7.0 \% \\ 1929 & 8.7 \% & 15.6 \% & 10.3 \% & 22.6 \% & 7.6 \% \\ 1930 & 5.8 \% & 13.5 \% & 7.6 \% & 15.4 \% & 5.9 \% \\ 1931 & 20.4 \% & 34.0 \% & 23.9 \% & 26.3 \% & 23.4 \% \\ 1932 & 30.5 \% & 44.3 \% & 34.4 \% & 38.6 \% & 33.5 \% \\ 1933 & 29.5 \% & 46.0 \% & 34.2 \% & 41.7 \% & 32.5 \% \\ 1934 & 27.6 \% & 43.2 \% & 32.0 \% & 32.9 \% & 31.9 \% \\ 1935 & 21.6 \% & 38.6 \% & 26.5 \% & 20.0 \% & 27.8 \% \\ 1936 & 14.2 \% & 33.2 \% & 19.5 \% & 20.2 \% & 19.4 \% \\ 1937 & 5.1 \% & 17.7 \% & 8.6 \% & 9.4 \% & 8.4 \% \\ 1938 & 3.4 \% & 11.0 \% & 5.5 \% & 4.4 \% & 5.7 \% \\ 1939 & 1.6 \% & 6.9 \% & 3.0 \% & 3.7 \% & 2.8 \%\end{array}$

"Core Employment" equals employers, wage/salary earners, self-employed.

"Unemployment" includes "partly unemployed", "relative assisting", "not specified". 
Appendix 3. Disaggregation of Working-Age Population

\begin{tabular}{llllllll}
\hline \multirow{2}{*}{$\begin{array}{l}\text { March } \\
\text { est. }\end{array}$} & $14-20$ & MALES & & & \multicolumn{3}{l}{ FEMALES } \\
\hline Population & & & $14-64$ & $14-64$ & $14-20$ & $21-64$ & $14-64$ \\
\hline & & & & & & \\
1921 & 76,400 & 331,300 & 407,700 & 74,200 & 317,900 & 392,100 \\
1922 & 79,000 & 340,200 & 419,200 & 76,700 & 328,500 & 405,200 \\
1923 & 81,600 & 346,700 & 428,300 & 79,300 & 335,800 & 415,100 \\
1924 & 84,300 & 354,300 & 438,600 & 81,600 & 343,500 & 425,100 \\
1925 & 87,600 & 364,900 & 452,500 & 83,800 & 352,800 & 436,600 \\
1926 & 89,900 & 373,100 & 463,000 & 85,800 & 360,000 & 445,800 \\
1927 & 92,400 & 380,700 & 473,100 & 87,700 & 367,600 & 455,300 \\
1928 & 94,200 & 387,100 & 481,300 & 89,000 & 374,300 & 463,300 \\
1929 & 95,100 & 394,500 & 489,600 & 90,300 & 381,600 & 471,900 \\
1930 & 95,900 & 402,800 & 498,700 & 90,800 & 388,900 & 479,700 \\
1931 & 97,100 & 411,000 & 508,100 & 92,200 & 396,200 & 488,400 \\
1932 & 96,000 & 416,400 & 512,400 & 91,800 & 402,000 & 493,800 \\
1933 & 94,700 & 421,900 & 516,600 & 90,800 & 408,100 & 498,900 \\
1934 & 94,100 & 427,900 & 522,000 & 90,600 & 413,700 & 504,300 \\
1935 & 94,700 & 431,700 & 526,400 & 91,200 & 418,300 & 509,500 \\
1936 & 95,200 & 432,300 & 527,500 & 91,700 & 422,700 & 514,400 \\
1937 & 95,300 & 438,200 & 533,500 & 91,600 & 428,500 & 520,100 \\
1938 & 95,300 & 444,500 & 539,800 & 91,200 & 434,600 & 525,800 \\
1939 & 96,400 & 451,300 & 547,700 & 92,200 & 440,800 & 533,000
\end{tabular}

Non-Participation Rate

$\begin{array}{lllllll}1921 & 22.5 \% & 2.7 \% & 6.4 \% & 51.6 \% & 76.6 \% & 71.9 \% \\ 1922 & 22.5 \% & 2.7 \% & 6.4 \% & 51.6 \% & 76.1 \% & 71.5 \% \\ 1923 & 23.2 \% & 2.7 \% & 6.6 \% & 53.8 \% & 75.6 \% & 71.5 \% \\ 1924 & 26.2 \% & 2.7 \% & 7.2 \% & 56.1 \% & 76.7 \% & 72.8 \% \\ 1925 & 28.0 \% & 2.7 \% & 7.6 \% & 58.4 \% & 77.8 \% & 74.0 \% \\ 1926 & 26.0 \% & 4.6 \% & 8.7 \% & 56.4 \% & 77.8 \% & 73.7 \% \\ 1927 & 23.1 \% & 4.4 \% & 8.1 \% & 54.5 \% & 75.8 \% & 71.7 \% \\ 1928 & 23.5 \% & 4.3 \% & 8.1 \% & 55.5 \% & 73.8 \% & 70.3 \% \\ 1929 & 24.0 \% & 4.3 \% & 8.1 \% & 56.5 \% & 73.8 \% & 70.5 \% \\ 1930 & 24.0 \% & 4.3 \% & 8.1 \% & 56.5 \% & 73.8 \% & 70.5 \% \\ 1931 & 20.5 \% & 4.3 \% & 7.4 \% & 52.0 \% & 68.9 \% & 65.7 \% \\ 1932 & 19.0 \% & 4.3 \% & 7.1 \% & 47.3 \% & 64.0 \% & 60.9 \% \\ 1933 & 19.0 \% & 4.3 \% & 7.0 \% & 47.3 \% & 64.0 \% & 61.0 \% \\ 1934 & 19.0 \% & 4.3 \% & 7.0 \% & 47.4 \% & 64.0 \% & 61.0 \% \\ 1935 & 19.0 \% & 4.1 \% & 6.8 \% & 47.4 \% & 64.0 \% & 61.0 \% \\ 1936 & 19.0 \% & 3.9 \% & 6.6 \% & 48.2 \% & 64.5 \% & 61.6 \% \\ 1937 & 19.0 \% & 3.9 \% & 6.6 \% & 49.1 \% & 65.1 \% & 62.3 \% \\ 1938 & 19.0 \% & 4.2 \% & 6.8 \% & 50.2 \% & 66.6 \% & 63.8 \% \\ 1939 & 20.0 \% & 4.4 \% & 7.2 \% & 51.2 \% & 68.1 \% & 65.2 \%\end{array}$


Appendix 3 continued

\begin{tabular}{lllllll} 
March & \multicolumn{3}{c}{ MALES } & \multicolumn{3}{c}{ FEMALES } \\
est. & $14-20$ & $21-64$ & $14-64$ & $14-20$ & $21-64$ & $14-64$
\end{tabular}

Core Employment Rate

$\begin{array}{lllllll}1921 & 69.5 \% & 94.5 \% & 89.8 \% & 43.5 \% & 20.9 \% & 25.1 \% \\ 1922 & 67.0 \% & 91.1 \% & 86.6 \% & 43.5 \% & 20.2 \% & 24.6 \% \\ 1923 & 65.1 \% & 95.7 \% & 89.9 \% & 41.2 \% & 21.5 \% & 25.2 \% \\ 1924 & 67.4 \% & 94.9 \% & 89.6 \% & 40.7 \% & 20.7 \% & 24.5 \% \\ 1925 & 63.2 \% & 96.6 \% & 90.1 \% & 37.7 \% & 21.0 \% & 24.2 \% \\ 1926 & 64.5 \% & 94.1 \% & 88.4 \% & 40.7 \% & 20.4 \% & 24.3 \% \\ 1927 & 66.5 \% & 90.1 \% & 85.5 \% & 42.2 \% & 20.8 \% & 25.0 \% \\ 1928 & 57.4 \% & 91.5 \% & 84.9 \% & 35.8 \% & 21.7 \% & 24.4 \% \\ 1929 & 57.9 \% & 90.0 \% & 83.8 \% & 34.7 \% & 22.6 \% & 24.9 \% \\ 1930 & 61.4 \% & 92.5 \% & 86.5 \% & 40.0 \% & 22.1 \% & 25.5 \% \\ 1931 & 55.8 \% & 77.6 \% & 73.4 \% & 38.3 \% & 19.0 \% & 22.6 \% \\ 1932 & 47.2 \% & 68.0 \% & 64.1 \% & 35.2 \% & 18.7 \% & 21.7 \% \\ 1933 & 44.5 \% & 69.8 \% & 65.1 \% & 33.6 \% & 18.2 \% & 21.0 \% \\ 1934 & 51.5 \% & 70.3 \% & 66.9 \% & 38.4 \% & 18.4 \% & 22.0 \% \\ 1935 & 61.8 \% & 75.2 \% & 72.8 \% & 45.3 \% & 19.1 \% & 23.8 \% \\ 1936 & 62.3 \% & 84.0 \% & 80.1 \% & 43.8 \% & 21.5 \% & 25.5 \% \\ 1937 & 71.4 \% & 92.6 \% & 88.8 \% & 48.3 \% & 27.3 \% & 31.0 \% \\ 1938 & 78.3 \% & 92.5 \% & 90.0 \% & 46.7 \% & 29.2 \% & 32.2 \% \\ 1939 & 77.6 \% & 94.4 \% & 91.4 \% & 46.5 \% & 29.5 \% & 32.4 \%\end{array}$

\section{Residual Participation Rate (“Unemployment”)}

$\begin{array}{lllllll}1921 & 8.0 \% & 2.9 \% & 3.8 \% & 4.8 \% & 2.5 \% & 2.9 \% \\ 1922 & 10.5 \% & 6.2 \% & 7.0 \% & 4.8 \% & 3.7 \% & 3.9 \% \\ 1923 & 11.8 \% & 1.6 \% & 3.5 \% & 4.9 \% & 2.9 \% & 3.3 \% \\ 1924 & 6.4 \% & 2.4 \% & 3.2 \% & 3.2 \% & 2.6 \% & 2.7 \% \\ 1925 & 8.8 \% & 0.7 \% & 2.3 \% & 3.9 \% & 1.2 \% & 1.7 \% \\ 1926 & 9.5 \% & 1.3 \% & 2.9 \% & 2.9 \% & 1.8 \% & 2.0 \% \\ 1927 & 10.5 \% & 5.5 \% & 6.5 \% & 3.3 \% & 3.4 \% & 3.4 \% \\ 1928 & 19.1 \% & 4.1 \% & 7.1 \% & 8.7 \% & 4.5 \% & 5.3 \% \\ 1929 & 18.1 \% & 5.7 \% & 8.1 \% & 8.9 \% & 3.6 \% & 4.6 \% \\ 1930 & 14.6 \% & 3.2 \% & 5.4 \% & 3.5 \% & 4.1 \% & 4.0 \% \\ 1931 & 23.7 \% & 18.1 \% & 19.2 \% & 9.8 \% & 12.2 \% & 11.7 \% \\ 1932 & 33.9 \% & 27.6 \% & 28.8 \% & 17.5 \% & 17.3 \% & 17.4 \% \\ 1933 & 36.5 \% & 25.9 \% & 27.9 \% & 19.1 \% & 17.9 \% & 18.1 \% \\ 1934 & 29.4 \% & 25.4 \% & 26.1 \% & 14.3 \% & 17.6 \% & 17.0 \% \\ 1935 & 19.2 \% & 20.6 \% & 20.4 \% & 7.3 \% & 16.9 \% & 15.2 \% \\ 1936 & 18.7 \% & 12.1 \% & 13.3 \% & 8.0 \% & 14.0 \% & 12.9 \% \\ 1937 & 9.6 \% & 3.5 \% & 4.6 \% & 2.6 \% & 7.6 \% & 6.7 \% \\ 1938 & 2.7 \% & 3.3 \% & 3.2 \% & 3.1 \% & 4.2 \% & 4.0 \% \\ 1939 & 2.4 \% & 1.2 \% & 1.4 \% & 2.3 \% & 2.4 \% & 2.4 \%\end{array}$

"Core Employment" consists of employers, wage/salary earners, \& the self-employed.

"Unemployment" includes those "partly unemployed", assisting without pay, and "not specified". 